TAO, Vol. 16, No. 3, 621-640, August 2005

\title{
Morphology, Hydrodynamics and Sediment Characteristics of the Changyun Sand Ridge offshore Western Taiwan
}

\author{
Horng-Ru Liao ${ }^{1}$ and Ho-Shing $\mathrm{Yu}^{1, *}$
}

(Manuscript received 10 January 2005, in final form 29 May 2005)

\begin{abstract}
The Changyun Ridge, a shelf sand ridge located off the western coast of Taiwan, is a tide-dominated sand body. This ridge is defined by the 50-m isobath and consists of two smaller ridges. The eastern Changyun Ridge is about $65 \mathrm{~km}$ long and $15 \mathrm{~km}$ wide and approximately parallel to the western shoreline of Taiwan. The western Changyun Ridge has a length of $53 \mathrm{~km}$ and a maximum width of $26 \mathrm{~km}$, trending northwest-southeast normal to the Taiwan western coast. The eastern ridge has morphologic characteristics similar to those of typical linear sand ridges. Tidal currents show distinct bidirectional patterns with speeds exceeding $100 \mathrm{~cm} \mathrm{~s}^{-1}$ strong enough to move sandy sediments. Large to very large sand waves occur on the western Changyun Ridge and sand waves seldom appear on the eastern Changyun Ridge, implying that the former is presently active while the latter becomes inactive or moribund. The configuration and distribution of these two ridges further suggest that the ridges developed sequentially from near-shore to offshore, presumably in response to a westward progressive decrease in velocity and change of flow direction of the north-flowing tidal currents.

Following the transgression beginning about 15000 years ago, the sea waters from the South China Sea began to flow over the sea floor between the Penghu Islands and Taiwan and the paleo-tidal currents finally excavated the sea bed into a channel now known as the Penghu Channel. Sands and mud are winnowed out but gravel and shell fragments have lagged behind in the Penghu Channel and only medium to fine-grained sands and mud carried by the strong tidal currents to the Changyun Ridge and beyond.
\end{abstract}

\footnotetext{
1 Institute of Oceanography, National Taiwan University,Taipei, Taiwan, ROC

* Corresponding author address: Prof. Ho-Shing Yu, Institute of Oceanography, National Taiwan University, Taipei, Taiwan, ROC;E-mail: yuhs@ccms.ntu.edu.tw
} 


\begin{abstract}
Mainly medium to coarse-grained sands have accumulated on the Changyun Ridge to form sand banks. At the northern outlet of the Penghu Channel, the shoaling topography of the Changyun Ridge has caused a decrease in tidal current velocity and the subsequent deposition of sands, forming the present Changyun sand ridge. The formation of the eastern and western Changyun sand ridges is probably affected mostly by the tidal current patterns in the areas north of the Penghu Channel.
\end{abstract}

(Key words: Sand ridge, Morphology, Hydrodynamics, Origin, Taiwan)

\title{
1. INTRODUCTION
}

\subsection{Submarine Topography}

The island of Taiwan is located at the junction of the Luzon and Ryukyu Arcs in the northwestern Pacific (Fig. 1). The island is bordered to the west by the shallow Taiwan Strait and by the deep Philippine Sea to the east. The Taiwan Strait is more than $300 \mathrm{~km}$ long and varies in width from 140 to $200 \mathrm{~km}$ between the east coast of Mainland China and the western shoreline of Taiwan (Fig. 1). The major part of the Taiwan Strait is shallower than $60 \mathrm{~m}$ (Boggs et al. 1979).

The broad sea floor in the strait is called the Taiwan Strait Shelf which is underlain by Cenozoic sediments more than $6000 \mathrm{~m}$ thick (Sun 1982). Tectonically, the Taiwan Strait Shelf is the southward continuation of the East China Sea Shelf and extends southwards to the South China Sea Shelf along the southeastern Chinese continental margin and follows the NE-SW regional structural trend (Fig. 1).

Despite the low-relief surface of the Taiwan Strait Shelf, the noticeable NE-SW trending Wuchu Depression exists in the western region of the Taiwan Strait (Fig. 1) and is about $125 \mathrm{~km}$ long and $16 \mathrm{~km}$ wide with an average water depth of about $70 \mathrm{~m}$ (Mao and Hsieh 1989). East of the southern part of this depression is the Changyun Ridge, a bathymetric high confined by a 50-m isobath. The Changyun Ridge extends westward about $90 \mathrm{~km}$ from the western shoreline of Taiwan, forming an E-W trending bathymetric ridge. The prominent N-S trending Penghu Channel occurs south of the Changyun Ridge. It occupies the waterway between the Penghu Islands and southwestern Taiwan and extends southwards to the northern slope of the South China Sea. The head of this channel may connect to the Wuchu Depression near the western edge of the Changyun Ridge (Liu et al. 1998). The Penghu Channel is about $120 \mathrm{~km}$ long and $20 \mathrm{~km}$ wide (Huang and $\mathrm{Yu}$ 2003). Southwest of the Penghu Islands is the southern Taiwan Strait where the Taiwan Banks, large bathymetric highs consisting of more than 30 shoals with water depths between 20 to $40 \mathrm{~m}$, are major submarine topographic features (Mao and Hsieh 1989). For detailed descriptions of the topography of the sea floor around Taiwan, including the Taiwan Strait Shelf, refer to Boggs et al. (1979), Mao and Hsieh (1989), Liu et al. (1998), Yu and Chou (2001) and Yu (2003). 


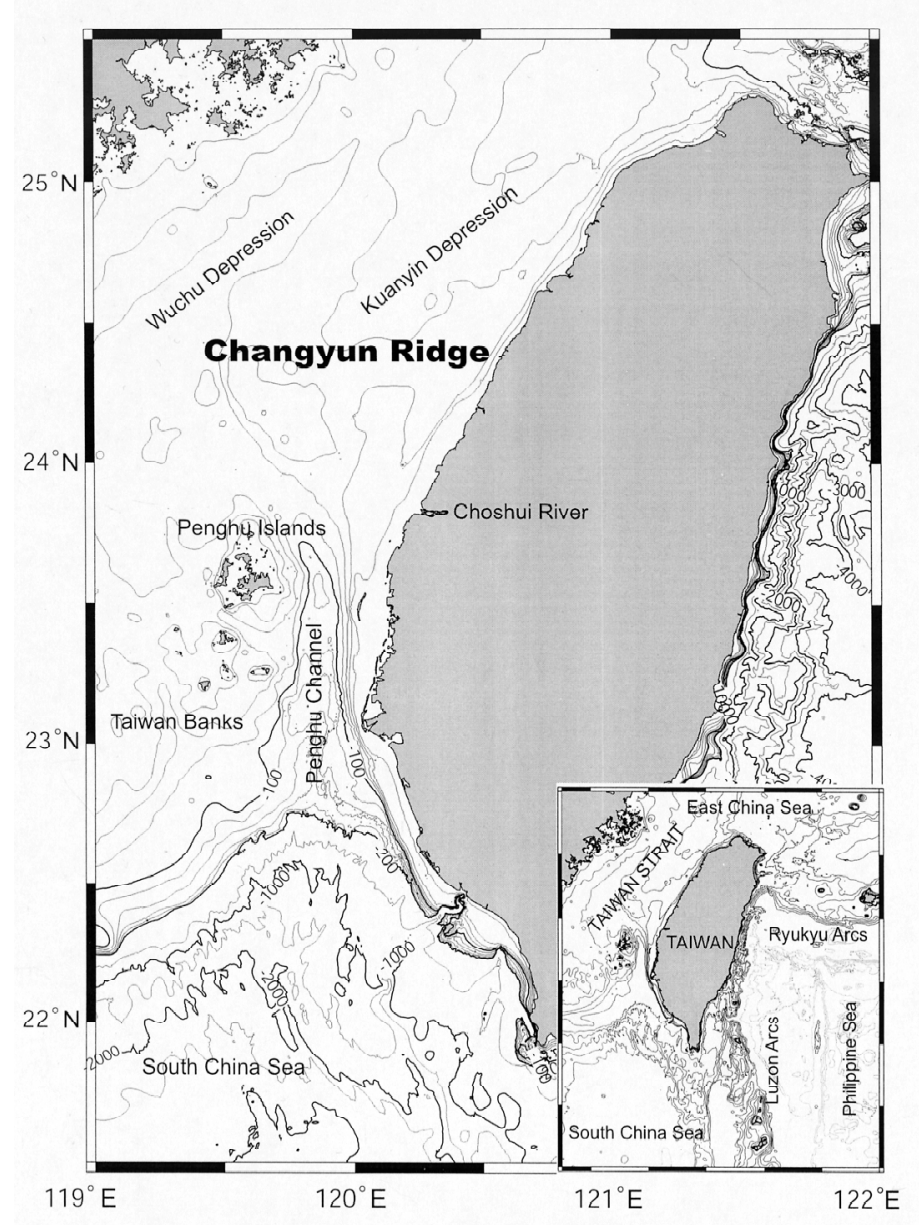

Fig. 1. Bathymetric map showing the shallow shelf off the western Taiwan coast characterized by four major topographic features. Located west of the Choshui River, the Changyun Ridge is flanked by the Kuanyin Depression to the north and by the Penghu Channel to the south and by the Wuchu Depression to the west. Contour interval is $20 \mathrm{~m}$ for the bathymetric chart covering the Taiwan Strait.

\subsection{Topography and Geological Implications}

Boggs et al. (1979) noticed that the general size, shape and orientation of bathymetric lows and highs in the Taiwan Strait are inconsistent with known hydrodynamic patterns and considered them to be probably relict in origin. Furthermore, they postulated that most of the Taiwan Strait Shelf was exposed subaerially and paleo-drainage developed on the exposed shelf during low sea levels about 15000 years ago. However, Huang and Yu (2003) suggested 
that the hypothesis of an ancient Minchang River flowing from China and extending eastward as well as connecting to the Penghu Channel on the exposed Taiwan Strait during Late Pleistocene is not supported by evidence of bathymetric data and modern hydrodynamics.

Considering the sedimentological aspects of tidal erosion-deposition, Liu et al. (1998) postulated that the Taiwan Strait is a modern tidal deposition system that consists of two tidal erosional and depositional geomorphic units, similar to what they observed on the shelf of the Bohai Sea. The paired Taiwan Strait's scour furrow (Wuchu Depression) and the Taiwan Banks (sand ridges) exist in the central and southern Taiwan Strait (Fig. 1). The second tidal erosion and deposition system is the Penghu Channel (scour furrow) and Changyun Ridge (sand ridge) occurring in the southeastern part of Taiwan Strait. Liu et al. (1998) emphasized the important role of tidal currents in the erosion and transportation of sediments, resulting in a paired scour furrow and sand ridge. Using $3.5 \mathrm{kHz}$ echograms and sediment samples, Huang and $\mathrm{Yu}$ (2003) considered the Penghu Channel to be a scour furrow but did not pay attention to the Changyun Ridge.

\subsection{Topography and Hydrography}

Generally, currents in the Taiwan region vary consistently from season to season (Liang et al. 2003). That said, currents in the Taiwan Strait are not only affected by seasonal sea surface wind stresses but also by the topographic relief of the Changyun Ridge and the Penghu Channel (Fan 1982; Wang and Chern 1992; Jan et al. 2002). During summer, the South China Sea surface waters driven by the southwesterly summer monsoon enter into the Taiwan Strait through the Penghu Channel (Fig. 2). The light surface waters flow over the Changyun Ridge and continue along the western coast of Taiwan and finally merge into the East China Sea. In contrast, the heavy bottom waters in the Penghu Channel are blocked in front of the Changyun Ridge and then are deflected northwestward. In winter, the northward flowing South China Sea waters through the Penghu Channel are retarded by the northeasterly winter monsoon and turn northwestward along the southern edge of the Changyun Ridge. In the northern Taiwan Strait, the southward cold and fresh China Coastal Waters turn cyclonically at the northern edge of the Changyun Ridge, forming a cyclonical cold eddy. An oceanic frontal zone develops on the Changyun Ridge. Jan et al. (2002) gave a detailed description of the seasonal circulation of currents in the Taiwan Strait.

The Taiwan Strait Shelf was considered to be one of several modern shelves characterized by semidiurnal tides with large tidal ranges $(3-4 \mathrm{~m})$ and strong surface currents $\left(60-100 \mathrm{~cm} \mathrm{~s}^{-1}\right)$ (Off 1963). Wang et al. (2003) updated the tidal currents in the Taiwan Strait, showing the yearly average tidal current being $0.46 \mathrm{~m} \mathrm{~s}^{-1}$, with the maximum amplitudes at the northeast and southeast entrances. There are only two direct flow measurements in the Penghu Channel. Chuang $(1985,1986)$ used a moored current meter to collect flow data and Wang et al. (2004) used a shipboard ADCP to map the flow field across the Penghu Channel. The former found a northward mean current of $0.27 \mathrm{~m} \mathrm{~s}^{-1}$ and tidal currents to about $1.0 \mathrm{~m} \mathrm{~s}^{-1}$. The latter determined the tidal velocity amplitudes to be $1.2 \mathrm{~m} \mathrm{~s}^{-1}$ and $0.32 \mathrm{~m} \mathrm{~s}^{-1}$, respectively. The funnelshaped Penghu Channel serves as a gate for water mass flux into the Taiwan Strait from the South China Sea. 

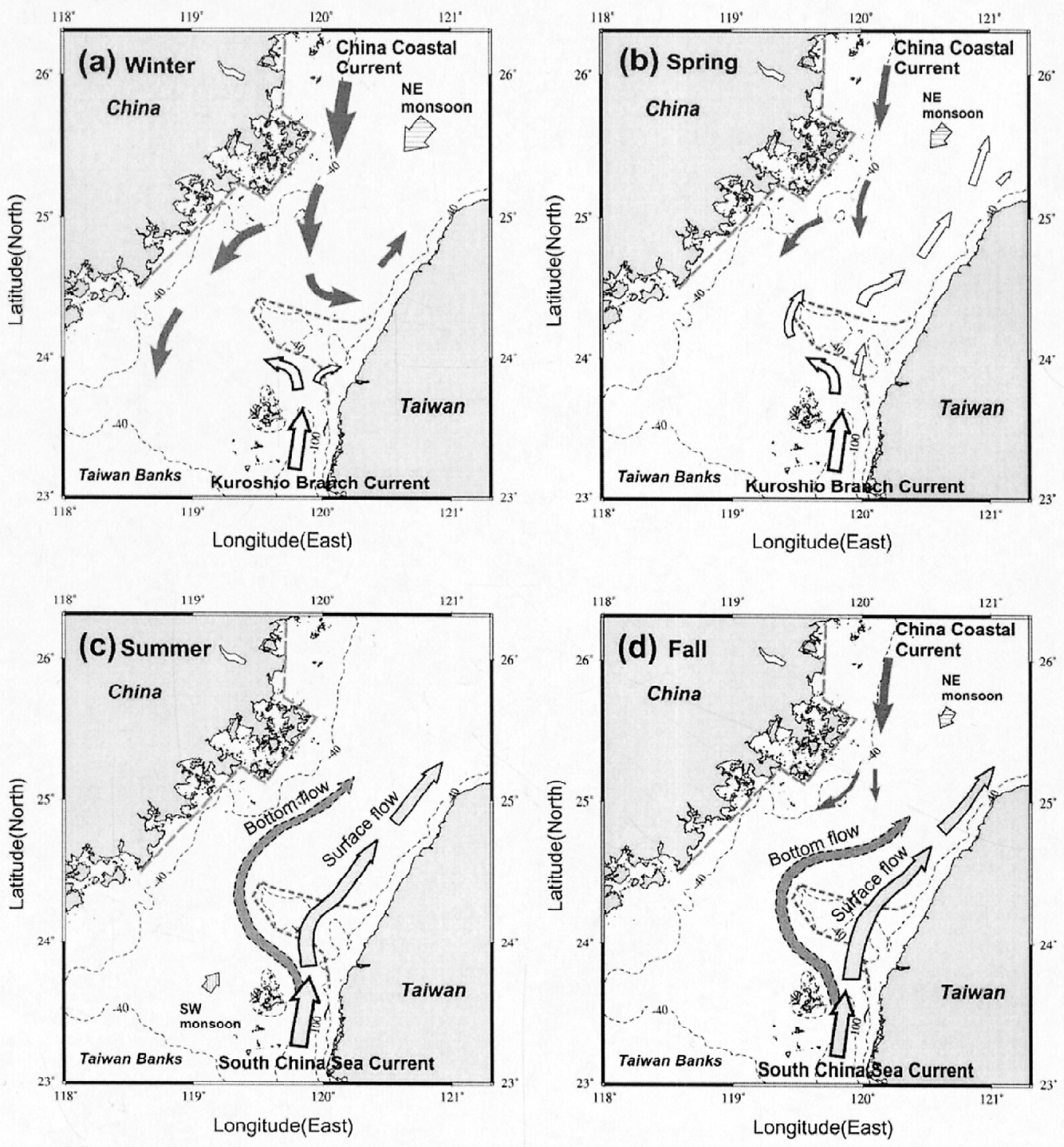

Fig. 2. The seasonal circulation of currents in the Taiwan Strait (Jan et al. 2002). Note that at the northern outlet of the Penghu Channel the currents are deflected to the northwest in front of the Changyun Ridge. In summer, north-flowing currents aided by southwestly monsoon flow over the Chanyun Ridge. Dash lines along the Chinese coast are the boundary of the numerical model for the seasonal circulation of currents in the Taiwan Strait. Dotted lines west of the Taiwan coast indicate the areal extent of the Changyun Ridge. 


\subsection{Changyun Sand Ridge}

The topographic high confined by the 40-m isobath north of the Penghu Channel was named as the Changyun sand ridge by Wang and Chern (1989). They found that north-flowing currents coming from the Penghu Channel were blocked by the Changyun sand ridge and deflected to the northwest along the southern edge of the ridge during the winter. The China Coastal Waters turned southeast and formed a cold front at the northern edge of the Changyun sand ridge. Although the topographic effect of the Changyun sand ridge on the current circulation in the Taiwan Strait was emphasized by Wang and Chern (1989), they didn't discuss in great detail sediment characteristics and morphology of the Changyun sand ridge. Sand ridges occur in many shelf seas where abundant sand is present and where strong tidal currents can move sediment and results in large offshore elongate sand bodies, known as tidal sand ridges or sand banks (Houbolt 1968; McCave and Langhorne 1982; Hulscher et al. 1993; Dyer and Huntley 1999; Williams et al. 2000). So whilst the Changyun sand ridge was loosely defined by Wang and Chern (1989), and other studies of sediment characteristics of the Changyun Ridge have emphasized grain size distribution and related sedimentary processes, there hasn't been much attention paid to the mechanism by which the sand ridge developed.

\subsection{Purpose}

This study aims to better understand geologic aspects of the Changyun sand ridge. We present up-to-date observations of morphology, hydrodynamics, movement and accumulation of sandy sediments along the Changyun sand ridge. This paper discusses the relationships between morphology, hydrodynamics and sediment characteristics, suggesting a possible origin of the Changyun Ridge.

\section{DATA}

Bathymetric profiles and cored surface sediment samples covering the Changyun Ridge were collected by short cruises of less than four days aboard the R/V Ocean Researcher I during 2002 - 2004 (Figs. 3a, c). The data were then integrated into the databank of bathymetry at the National Center for Ocean Research. Bathymetric charts using the GMT system were then plotted and contoured on a grid of one data point every $100 \mathrm{~m}$ in the study areas. Three four-channel seismic reflection profiles over the long axis of the eastern Changyun Ridge were acquired during cruise 685 of 2003 aboard R/V Ocean Researcher I (Fig. 3b) with an airgun-array being the seismic energy source, and recording of seismic signals performed by a DFS-V floating gain digital system. This seismic data were then processed using SIOSES and PROMAX programs at the Institute of Oceanography, National Taiwan University.

\section{MORPHOLOGY}

The bathymetric high north of the Penghu Channel and close to the western Taiwan coast 
was revealed by Boggs et al. (1979) but its real extent was not specifically defined (Fig. 1). This particular bathymetric high is best defined by a 50-m isobath, revealing a triangular shape narrowing toward the west (Fig. 4). It was named the Yunchang Rise (Yu and Song 2000); however, for the purposes of this study we follow the original name used by Wang and Chern (1989) who referred to it as the Changyun sand ridge (Fig. 4). As mentioned, the ridge is

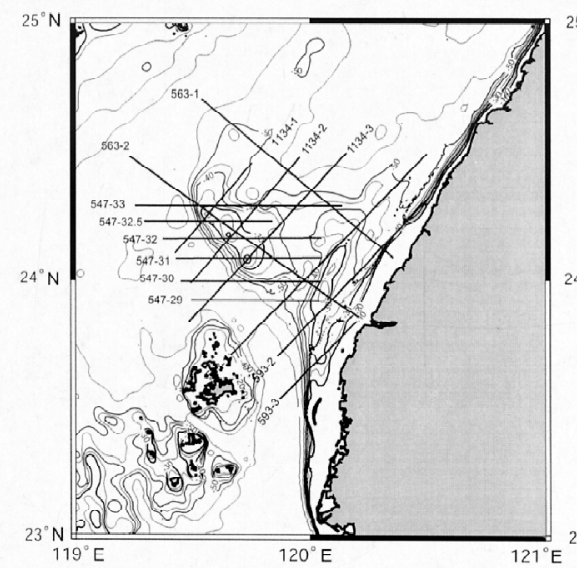

(a)

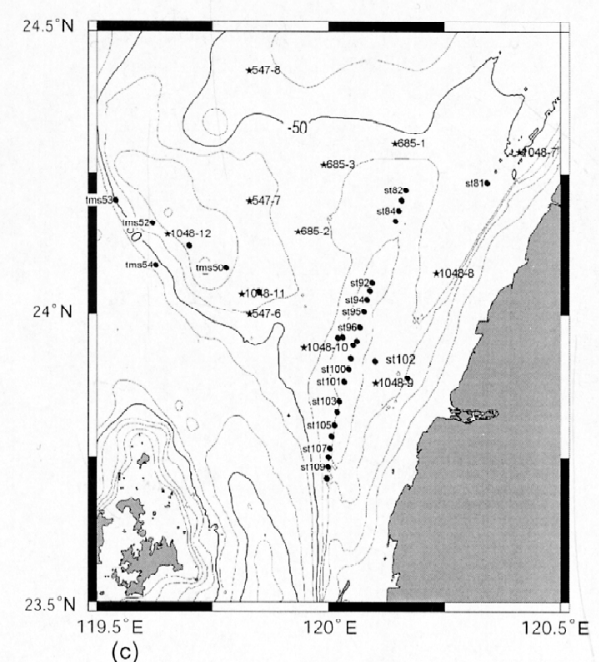

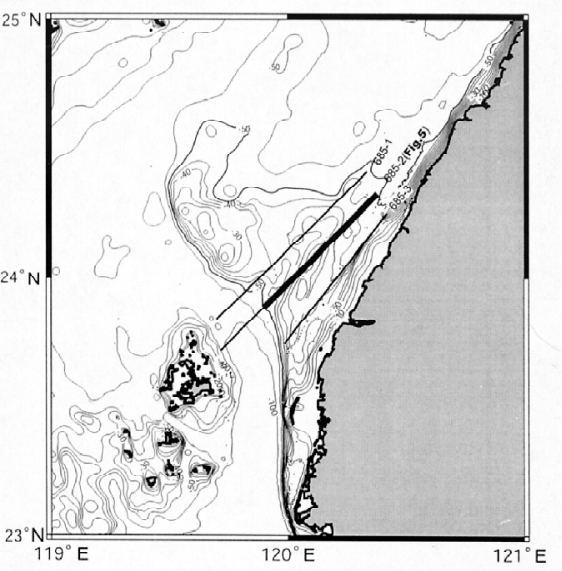

(b)

Fig. 3. Bathymetric profiles and surface sediments covered the Changyun Ridge were collected on board R/V Ocean Researcher I during 2002 - 2004 (Figs. 3a, c). Three four-channel seismic reflection profiles over the long axis of the eastern Changyun Ridge were acquired during cruise 685 in 2003 aboard the R/V Ocean Researcher I (Fig. 3b). denotes sediment samples collected by our surveys. indicates sediment samples from $\mathrm{Li}$ and Chen (2001). 


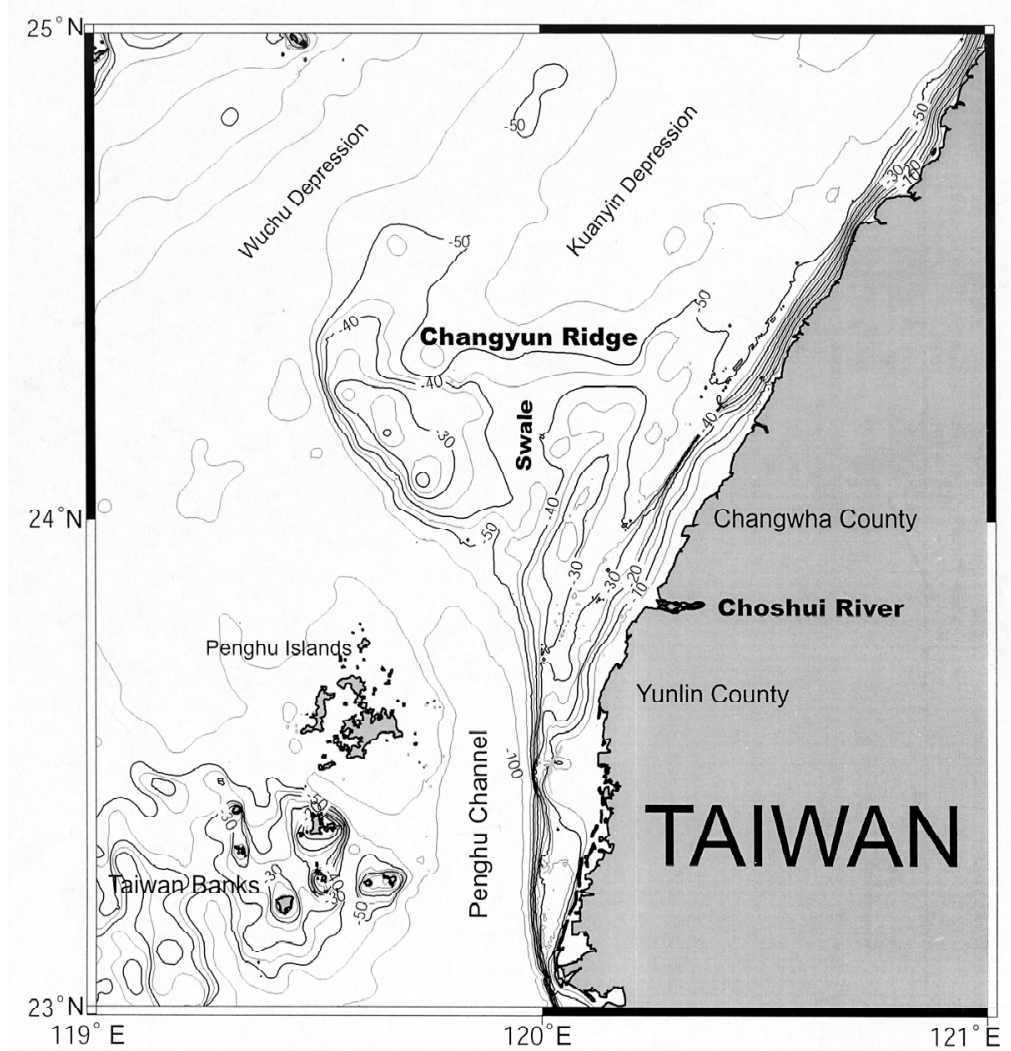

Fig. 4. The Changyun Ridge is characterized by a triangle shape tapering west bounded by longitude $119^{\circ} 30^{\prime} \mathrm{E}$. It consists of two parts: the east part with its long axis to the NE nearly parallel to the western coast of Taiwan. The western part has its long axis in a NW-SE direction. Note that the size of the eastern Changyun Ridge is similar to those of the common sand ridges (e.g., sand ridges on the North Sea shallow shelf). Contour interval $=5 \mathrm{~m}$.

characterized by a triangular shape tapering west and ending about longitude $119^{\circ} 30^{\prime} \mathrm{E}$. It can be divided into two parts: the eastern part with its long axis at an angle of 17 degrees to the NE nearly parallel to the west coast of Taiwan, and the western Changyun Ridge which has its long axis trending in a NW-SE direction.

The eastern Changyun sand ridge is located approximately $20 \mathrm{~km}$ offshore and is about $65 \mathrm{~km}$ long and $15 \mathrm{~km}$ wide. The eastern ridge shows an asymmetrical cross section with a steep side (about 0.2 degrees) to the west and a gentler slope to the east (about 0.11 degrees). The southern edge of the eastern ridge is relatively narrow while the northern edge tends to be relatively wide. The crest of the eastern ridge is defined by a $30-\mathrm{m}$ isobath, showing a relatively narrow 
linear sedimentary body stretching for a distance of about $45 \mathrm{~km}$. Sand ridges are typically of tens of kilometers in length and can be up to $80 \mathrm{~km}$ long and about $13 \mathrm{~km}$ wide and tens of meters high (Dyer and Huntley 1999; Williams et al. 2000). The dimensions of the eastern Changyun sand ridge are comparable to those of other common sand ridges, suggesting that the eastern ridge has typical sand ridge morphology.

The western Changyun sand ridge is separated from the eastern ridge by a swale about 8 to $10 \mathrm{~km}$ wide and 40 to $45 \mathrm{~m}$ deep (Fig. 4). The western ridge is $53 \mathrm{~km}$ long, has a maximum width of $26 \mathrm{~km}$ and a height above the sea floor varying from 20 to $30 \mathrm{~m}$. The axis of the western ridge runs nearly normal to the coastline and has a NW-SE orientation except at its seaward end where it is sharply curved to the northeast (Fig. 4). The location and orientation of the western sand ridge is quite different from that of typical sand ridges, implying other inherited effects on its morphology.

\section{HYDRODYNAMICS}

The origins of sand ridges or banks are closely related to hydrodynamic conditions and generally require tidal seas with current speeds greater than $0.5 \mathrm{~m} \mathrm{~s}^{-1}$ to move sand to form ridges (Caston 1972; Belderson et al. 1982; Pattiaratchi and Collins 1987; Dyer and Huntley 1999; Anthony and Leth 2002). Of particular, importance is the role of tidal currents (Stride 1982). The currents from the South China Sea converge at the funnel-shaped Penghu Channel, flow northward along the western Taiwan coast, and flow over the Changyun sand ridge (Liang et al. 2003). Similarly, Wang et al. (2004) found that currents flowing over the Changyun sand ridge are characterized by a net northward flow coming from the Penghu Channel to the south. However, they further separated the mean flow from tidal currents. The currents in the Penghu Channel are characterized by semidiurnal tides. The along-channel average tidal velocity amplitudes are $1.2 \mathrm{~m} \mathrm{~s}^{-1}$ and $0.32 \mathrm{~m} \mathrm{~s}^{-1}$ for semidiurnal and diurnal tides, respectively. The mean current is uniform and has an average northward velocity of $0.73 \mathrm{~m} \mathrm{~s}^{-1}$. In the vicinity of the Changyun sand ridge, tides are dominated by semidiurnal tide (M2) with amplitude as high as $2 \mathrm{~m}$ (Jan et al. 2004). It is clear that the strong northward flowing tidal currents from the Penghu Channel are mainly responsible for transporting sediment which accumulates at the Changyun sand ridge.

From geologic and historical perspectives, there exist two types of tidal sand banks. The first type rests on a flat surface where sands derived from a source area are deposited (Houbolt 1968; Belderson et al. 1982; Hulscher et al. 1993). This suggests a pure hydrodynamic origin of sand ridges. The second type of sand bank is formed by sand accumulation around a preexisting sedimentary body (Houbolt 1968; Laban and Schuttenhelm 1981; Yang 1989). They consist of cores of eroded fluvial, estuarine sediments or bedrock material of early Holocene or Pleistocene age, indicating polygenetic origin. Multi-channel reflection seismic section 685-2 across the Changyun Ridge shows no prominent feature underlying the Changyun Ridge (Fig. 5). Although seismic section 685-2 is not a high-resolution profile, it at least indicates that the Changyun Ridge is not affected by the prominent Peikang basement high located at the southeast of the Changyun Ridge. We suggest that the Changyun sand ridge is probably formed on 
a flat surface where sands derived from a source area are accumulated and built up. It implies that the Changyun sand ridge is probably a modern sand ridge formed during the last sea transgression.

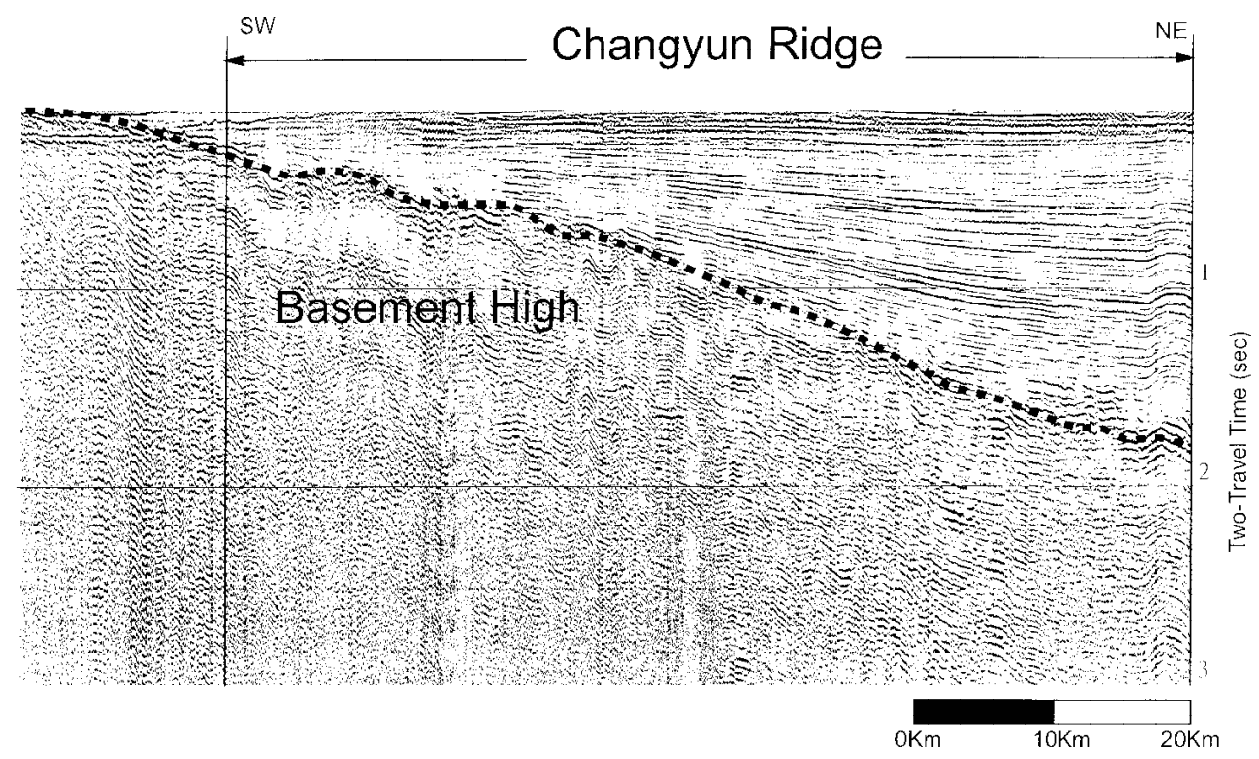

Fig. 5. Seismic section 685-2 (see Fig. 3b for location) shows that the Changyun Ridge is underlain by relatively flat and parallel reflections, indicating no structural uplift effect. Note that the Mesozoic Peikang basement high is unconformably overlain by Late Tertiary sediments.

\section{SEDIMENT CHARACTERISTICS}

The surface sediments of the Changyun sand ridge have been studied since 1974 (e.g., Boggs 1974) with emphasis on grain size analyses ( $\mathrm{Li}$ and Chen 2001). The distribution of grain size falls in the range from 0.12 to 4.03 phi and medium to coarse-grained sands are dominant. These sands are generally well sorted. Abundant sand waves are found on the crest and flanks of the western Changyun sand ridge with amplitudes ranging from 1 to $10 \mathrm{~m}$ with the majority between $3-5 \mathrm{~m}$. The wavelength of these sand waves ranges from 75 to $150 \mathrm{~m}$.

Grain size of surface sediments of the eastern Changyun Ridge ranges from 0.12 to 2.57 phi (Fig. 6). The crest of the eastern ridge is characterized by medium-to-coarse sands ( 0.12 to 1.78 phi) with two exceptions of fine sands of 2.22 phi and 2.57 phi, respectively (Fig. 6). The flanks of the eastern ridge have finer sediments as indicated by fine sand ( $2.28 \mathrm{phi}$ ) to the west and east (3.06 phi). The crest of the western Changyun Ridge is characterized by medium sands ranging from 1.35 to 2.00 phi (Fig. 7). This study shows that the Changyun Ridge is covered by coarser sands on the crest and finer sands on the flanks similar to other sand ridges 


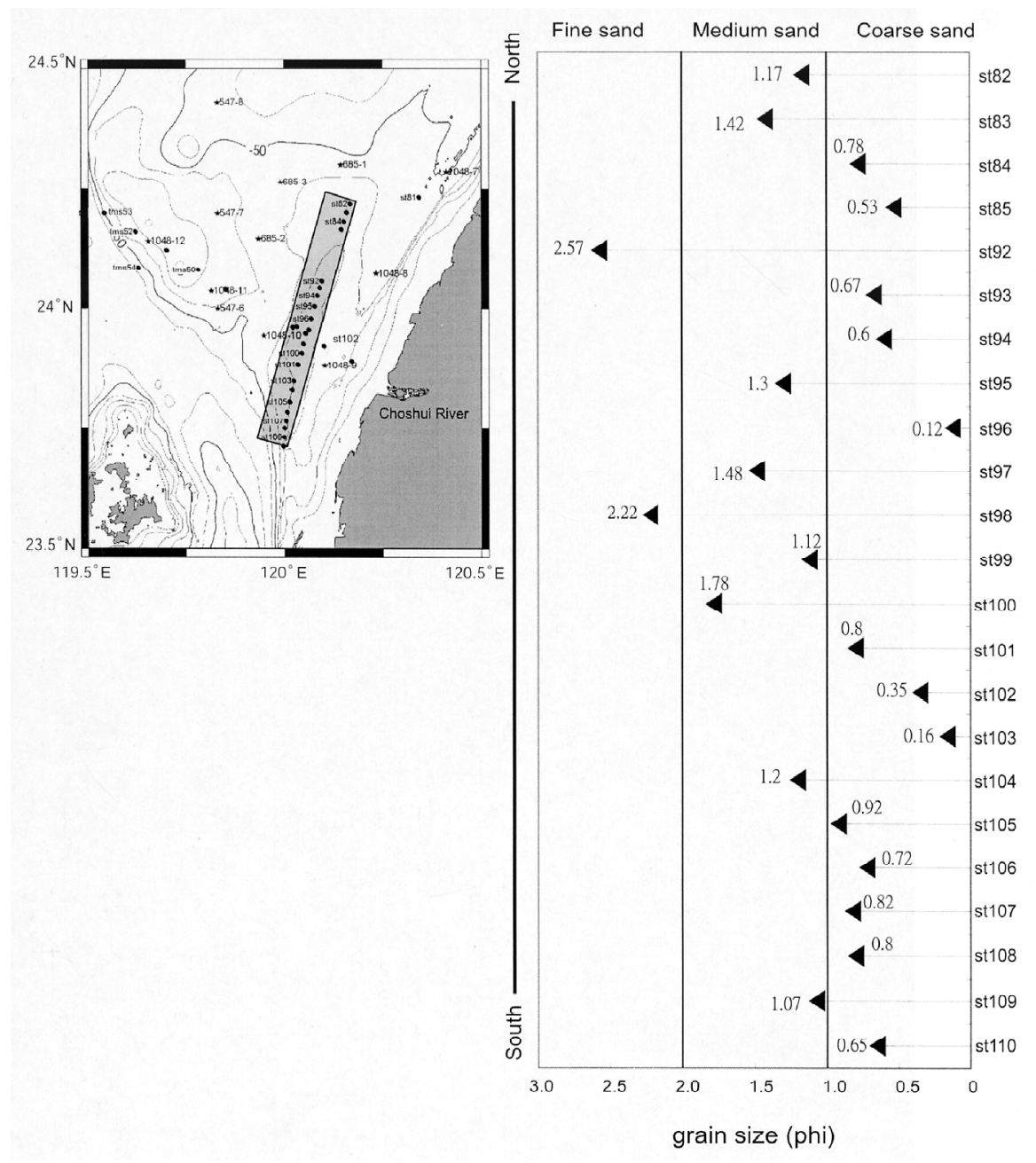

Fig. 6. The crest portion of eastern Changyun Ridge is dominated by medium to coarse-grained sands. Index map to the left shows the location of sediment samples.

(Liu et al. 1998), reflecting flow conditions similar to that of common sand ridges.

The presence or absence of sand waves on sand ridges indicates whether a sand ridge is active or not (Park et al. 2003). Sand waves on sand ridges result from an active response to present current flows. However, the absence of sand waves suggests that the morphology and development of a sand ridge is little changed or modified by the present hydrodynamic conditions on the shelf (Park and Lee 1994). Bathymetric profiles show that abundant sand waves occur on the western Changyun Ridge and sand waves seldom appear on the eastern Changyun 

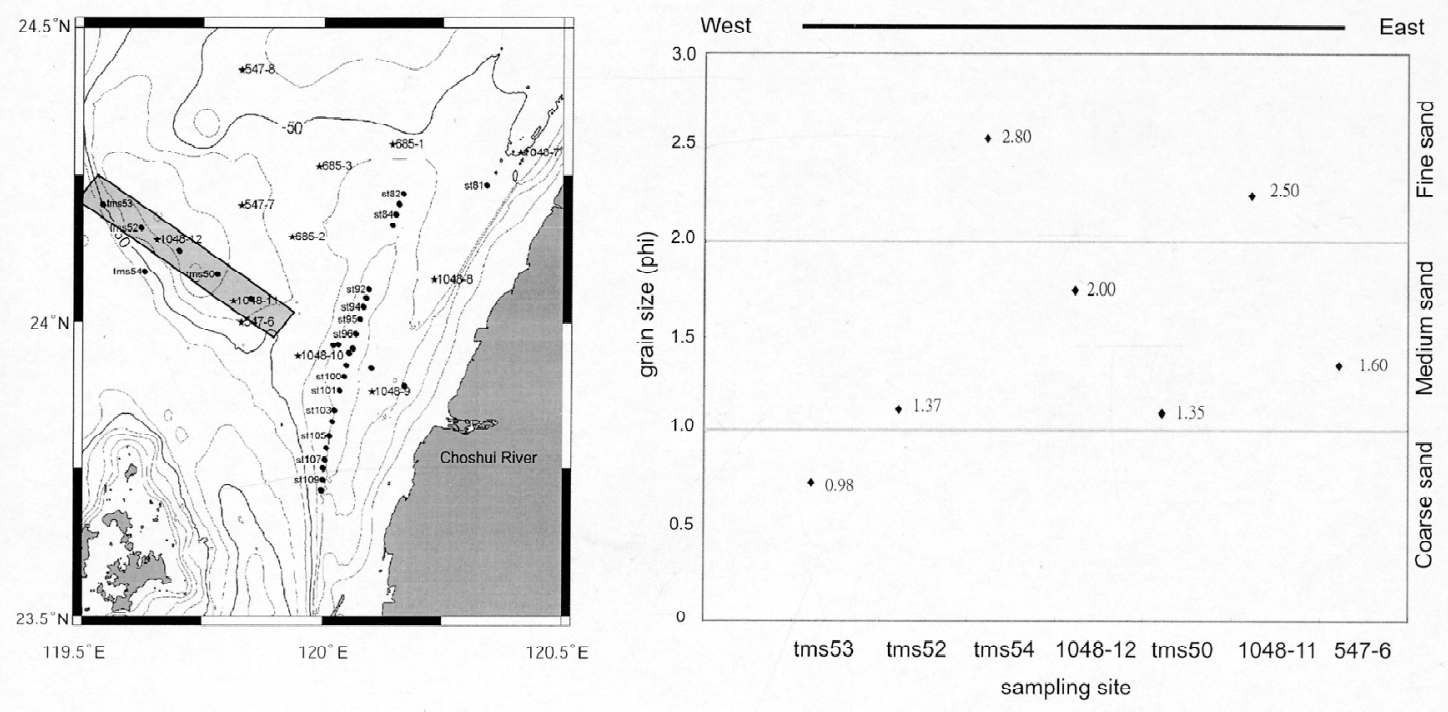

Fig. 7. Medium-grained sands are prevalent on the crest portion of the western Changyun Ridge. Index map to the left shows the location of sediment samples.

Ridge. The difference in the distribution of sand waves between the western and eastern ridges suggests that the western and eastern ridges are affected by different hydrodynamic processes. It implies that the shape and size of the eastern Changyun Ridge remain more or less the same at the present time, resulting from a near balance of addition and removal of sands. By contrast, the western Changyun Ridge continues receiving sand supply from sources to the south. The configuration and distribution of western and eastern ridges further suggest that the ridges developed sequentially from near-shore to offshore, presumably in response to a westward progressive decrease in velocity and change of flow direction of the north-flowing tidal currents. The shoaling topography of the east Changyun Ridge can cause a decrease in north-flowing current velocity and deflect the currents to flow northwestward along the southern edge of the Changyun Ridge. In other words, in the beginning of the development of the Changyun Ridge, the currents flowed northward over the proto-Changyun Ridge without topographic effect. After accumulation of a critical amount of sandy sediments in the formation of the infant eastern Changyun Ridge, the north-flowing currents were blocked in front of the ridge and were deflected northwestwards. Here the topographic high of the eastern Changyun Ridge began to affect north-flowing currents and accompanied sedimentation. This hypothesis ought be tested thoroughly in a future study.

The morphological characteristics of sand waves are indicative of the direction of prevalent current flows and associated sediment transport (Stride 1982; Dalrymple 1984; Lanckneus et al. 1994; Liu et al. 1998). Large to very large sand waves occur on the crest and both flanks of the western Changyun Ridge. Large sand waves have height between 0.5 and $3 \mathrm{~m}$ and the 
very large ones have heights greater than $3 \mathrm{~m}$ (Ashley, 1990). On the western Changyun Ridge the height of the large to very large sand waves ranges from 1 to $10 \mathrm{~m}$, the height commonly ranging from 3 to $5 \mathrm{~m}$. Here, the wavelength of the sand waves ranges from 200 to $300 \mathrm{~m}$. The angle of the steep slopes of the sand waves varies between $0.6-2$ degrees, with an average of 1.2 degrees. Stoss slopes have angles ranging from 2 to 4 degrees. The values of the slope angle of the sand waves on the western Changyun Ridge are considered relatively low, as compared to those reported by Berne et al. (1989).

Most large sand waves on the western Changyun Ridge show asymmetrical cross-sectional profiles (Figs. 8 and 9). The direction of peak currents is usually oriented at an angle to the crest lines of large sand waves (Dalrymple 1984; Lanckneus et al. 1994). Bathymetric profile 1134-2 shows the sand waves denoted as block A on the crest gently slope to the southwest and slope steeply to the northeast (Fig. 9). In contrast, sand waves marked by block $\mathrm{B}$ on the flank have a gentle slope to the northeast and a steep slope to the southwest. The reversing slope angles observed on the crest and flank of the sand ridge suggest bidirectional currents. The sand waves on the crest are mainly formed by northeast-flow currents probably being flood-tidal currents. In contrast, sand waves on the flank respond mainly to southwestflowing currents probably being ebb-tidal currents.

\section{ORIGIN}

Linear sand ridges or banks are found at many shelf sea locations, such as the North Sea (Berne et al. 1994), where abundant sands are brought in from other places by strong tidal currents and formed in the post-glacial transgressions (Yang 1989; Dyer and Huntley 1999; Park et al. 2003). Similarly, the sand ridges found along the tidally active Taiwan Strait shelf are the norm rather than the exception. Integrating observations of the morphology, hydrodynamics and sediment characteristics of the Changyun Ridge, we present a possible scenario for the origin of the Changyun sand ridge.

The global sea-level curve (Fairbanks 1989) indicates that sea level rose rapidly in the early to middle transgression period from 17000 to 7000 years BP, followed by a slow rise in the late period about 7000 years BP. Originating between 15000 and 5000 years BP, the Changyun Ridge was closely related to the Holocene sea transgression and associated sedimentation in the southeastern Taiwan Strait. As sea levels rose in the late Pleistocene about 15000 years ago, the sea transgressed northward and mainly passed the present-day Penghu Channel and then gradually advanced toward the China mainland. The sea reached its present level in the Taiwan Strait some 5000 to 7000 years ago (Boggs et al. 1979). The Holocene transgression in the Penghu Islands west of the Penghu Channel culminated at about 5000 years ago (Chen and Liu 1996). Modern sandy sediments derived from rivers in western Taiwan prograded seaward and westward for about 30 or $40 \mathrm{~km}$ at about $20 \mathrm{~m}$ deep (Boggs et al. 1979). This indicates that the Changyun Ridge and Penghu Channel appear not to be covered by modern sediments derived from Taiwanese rivers. With this in mind we discount the possibility of sediment input being derived from Taiwan island's estuary systems and coastlines and suggest as a sediment source erosion of the Penghu Channel. 

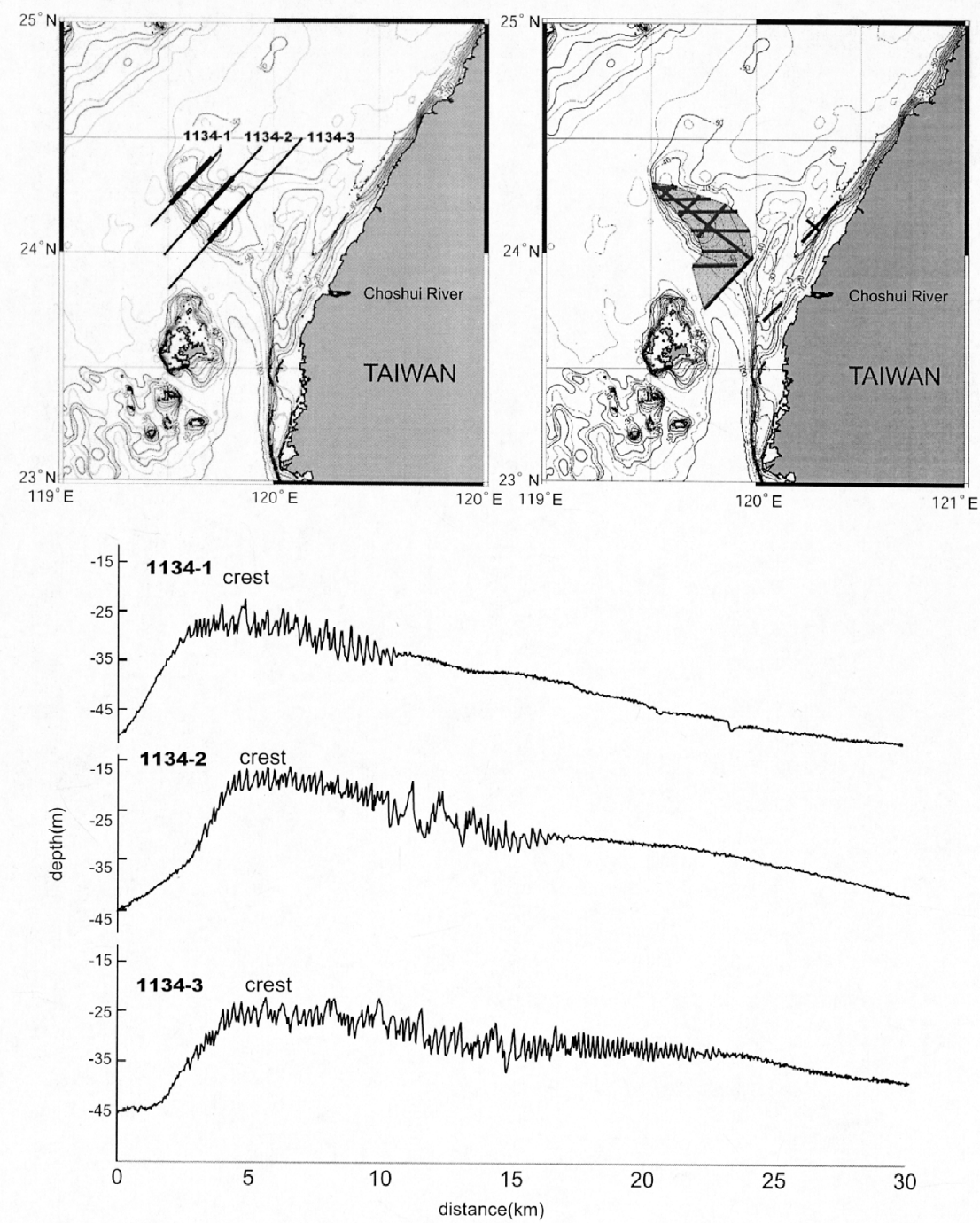

Fig. 8

Fig. 8. Most parts of the western Changyun sand ridges are superimposed by large to very large sand waves as indicated by shaded areas. In contrast, sand waves occur seldom on the eastern Changyun sand ridge. The presence or absence of sand waves implies that the western Changyun sand ridge is active but the east Changyun sand ridge has become moribund or inactive. Three bathymetric profiles across the western Changyun sand ridge show that sand waves occur mainly on the crest parts of the sand ridge. 


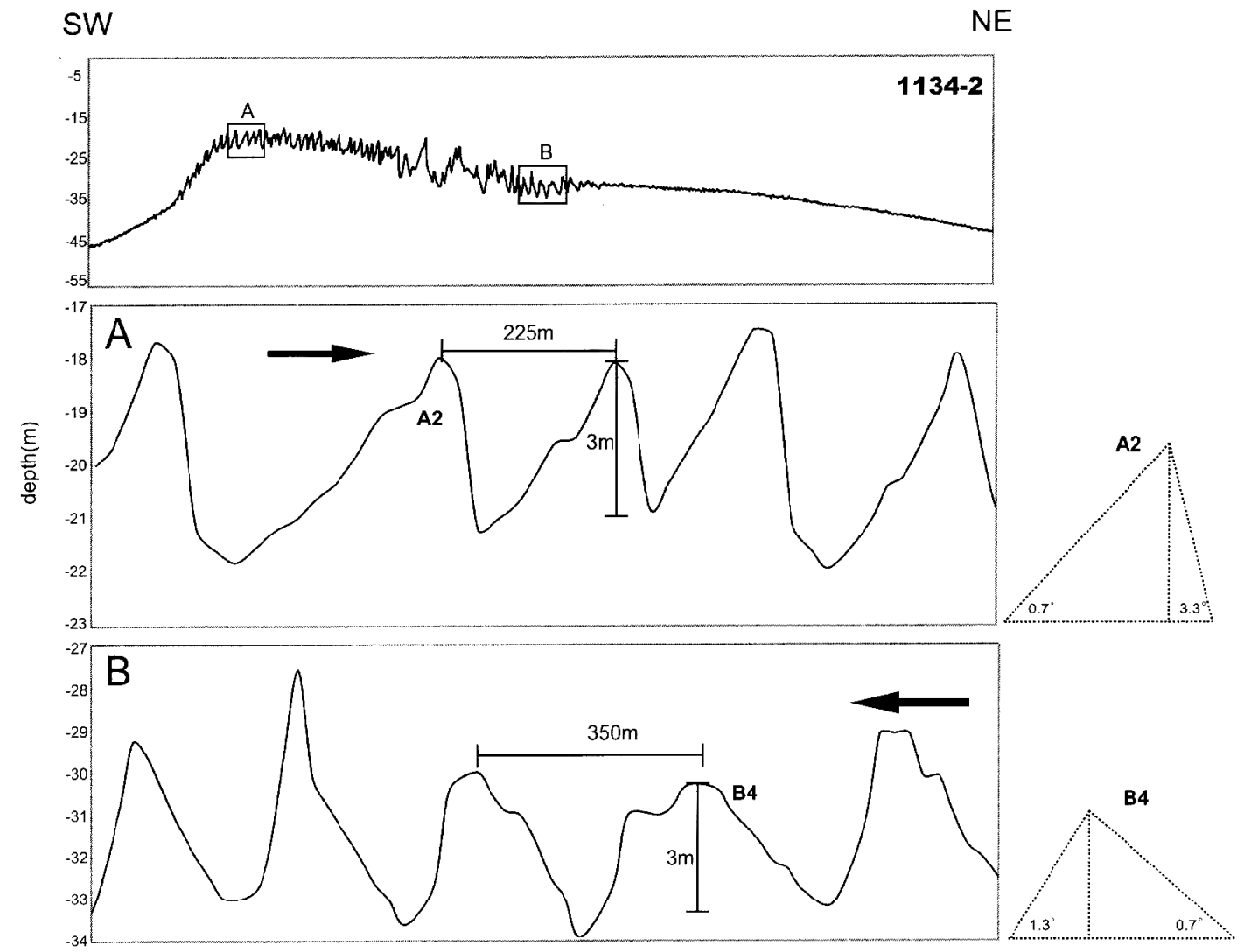

Fig. 9. Bathymetric profile 1134-2 shows the sand waves denoted as block A on the crest have a gentle slope to the southwest and a steep slope to the northeast. In contrast, sand waves marked by block B on the flank have a gentle slope to the northeast and a steep slope to the southwest. The reversing slope angles observed on the crest and flank of the sand ridge suggest bidirectional currents. The sand waves on the crest are mainly formed by northeast-flow currents probably being flood-tidal currents. In contrast, sand waves on the flank respond mainly to southwest-flowing currents probably being ebb-tidal currents.

Following the transgression beginning about 15000 years ago, the sea waters from the South China Sea began to flow over the sea floor between the Penghu Islands and Taiwan and the paleo-tidal currents finally excavated the sea bed into a channel now known as the Penghu Channel. Presently, the Penghu Channel is a scour furrow, evidenced by irregular grooves with relief between $20-70 \mathrm{~m}$ on the channel floor (Huang and Yu 2003). Strong tidal currents (greater than $1 \mathrm{~m} \mathrm{~s}^{-1}$ ) have caused erosion of the seabeds of the Penghu Channel, producing sandy sediments carried away by the north-flowing currents. Gravel, sands, and shell frag- 


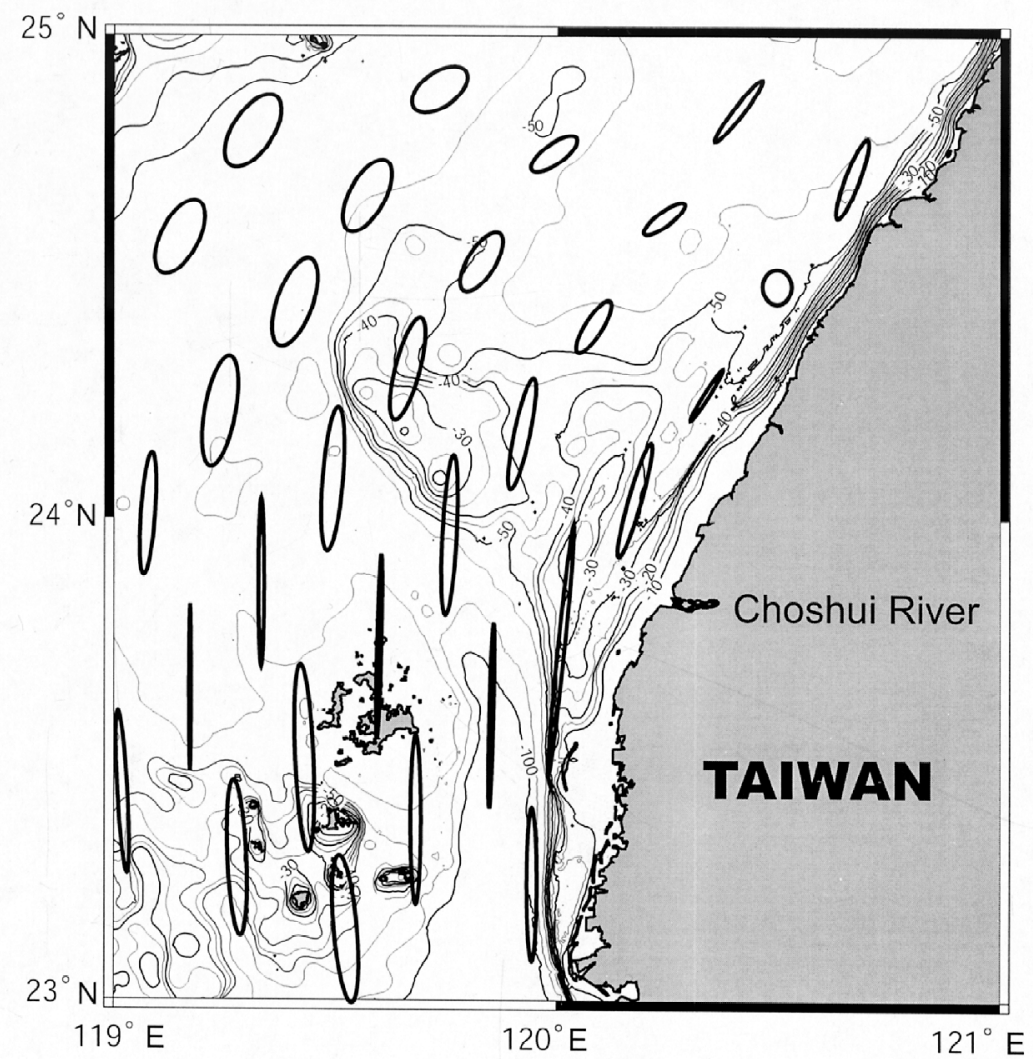

Fig. 10. Distribution patterns of semidiurnal tidal ellipses in the Taiwan Strait. The eastern Changyun sand ridge is dominated by relatively narrow ellipses, whereas relatively broad ellipses are prevalent over the western Changyun sand ridge. Modified from Wang et al. (2003).

ments are abundant with lesser amounts of silt and clay on the floor of the Penghu Channel (Huang and Yu 2003). It appears, the fine sands and mud have been winnowed out with the coarse-grained sands, gravel and shell fragments lagging behind in the channel. This has resulted in only medium to fine-grained sands and mud being carried away to the Changyun Ridge and beyond. Similarly, the floor of St. George's Channel is free of mud which has been removed by tidal currents in excess of $100 \mathrm{~cm} \mathrm{~s}^{-1}$ (Johnson 1978). Mainly medium-grained sands have accumulated on the Changyun Ridge to form sand banks. At the northern outlet of the Penghu Channel, the shoaling topography of the Changyun Ridge can cause a decrease in the tidal current velocity and subsequent deposition of fine-grained sands, forming the present Changyun sand ridge. A similar type of coupled sand ridge-scour channel occurs in the eastern Bohai Sea shelf (Liu et al. 1998). The formation of the eastern and western Changyun sand ridges may be mainly affected by the tidal current patterns in the areas north of the Penghu 
Channel. Liu et al (1988) pointed out that sand ridges are dominated by strong reciprocating currents with relatively narrow ellipses whereas rotating currents with relatively broad ellipses are prevalent over sand sheets. Applying this criterion to the Changyun Ridge to distinguish the eastern elongate sand ridge from the western broad sand ridge. Figure 10 shows that the eastern Changyun sand ridge is dominated by relatively narrow ellipses with strong reciprocating tidal currents, whereas relatively broad ellipses with rotating tidal currents are prevalent over the western Changyun sand ridge.

\section{CONCLUSIONS}

Detailed bathymetric mapping suggests that the Changyun sand ridge can be divided into two smaller ridges: the eastern sand ridge being about $65 \mathrm{~km}$ long and $15 \mathrm{~km}$ wide and parallel to the western shoreline of Taiwan, and a western ridge being about $53 \mathrm{~km}$ long and $26 \mathrm{~km}$ wide and trending NW-SE normal to the Taiwan western shoreline. Seismic reflection profiles indicate that the Changyun Ridge is underlain by relatively flat and parallel reflections, indicating no structural uplift effect but a dominant hydrodynamic origin. Tidal currents are the main factors influencing the movement of sandy sediments and the shaping of topographic features in the Changyun Ridge areas. Currents' data show that tidal currents are characterized by distinct bidirectional patterns with speeds exceeding $100 \mathrm{~cm} \mathrm{~s}^{-1}$ strong enough to move sandy sediments. Large to very large sand waves occur on the western Changyun Ridge and sand waves seldom appear on the eastern one, implying that the former is presently active while the latter has become inactive or moribund.

The Changyun Ridge and Penghu Channel may be considered together as a modern tidal deposition system. The Changyun sand ridge is the depositional site receiving sandy sediments mainly derived from the Penghu Channel via north-flowing strong tidal currents.

Acknowledgements We thank the captain, crew and technicians on board R/V Ocean Researcher I who helped to collect marine data. Z. X. Liu, Institute of Oceanography, Qindao, China, and James Liu, National Sun Yat-San University, Kaohsiung, Taiwan reviewed an early version of the manuscript. Constructive comments and suggestions by J. C. Chen and an anonymous reviewer improved the quality of this paper. This study is financially supported by the National Science Council, Taiwan, Republic of China.

\section{REFERENCES}

Anthony, D., and J. O. Leth, 2002: Large-scale bedforms, sediment distribution and sand mobility in the eastern North Sea off the Danish west coast. Mar. Geol., 182, 247-263.

Ashley, G. M., 1990: Classification of large-scale subaqueous bedforms: a new look at an old problem. J. Sediment. Petrol., 60, 160-172.

Belderson, R. H., M. A. Johnson, and N. H. Kenyon, 1982: Bedforms. In: Stride, A. H. (Ed.), Offshore Tidal Sands. Chapman \& Hall, London, 27-57. 
Berne, S., G. Allen, J. P. Auffret, H. Chamley, J. Durand, and O. Weber, 1989: A review of modern tidal giant dunes. Bull. Soc. Geol. France, 5, 1145-1160.

Berne, S., A. Trentesaux, A. Stolk, T. Missiaen, and M. De Batist, 1994: Architecture and long-term evolution of a tidal sandbank: the Middlekerke Bank (southern North Sea). Mar. Geol., 20, 57-72.

Boggs, S., 1974: Sand-wave fields in Taiwan Strait. Geology, 2, 251-253.

Boggs, S., W. C. Wang, F. S. Lewis, and J. C. Chen, 1979: Sediment properties and water characteristics of the Taiwan shelf and slope. Acta Oceanogr. Taiwanica, 10, 10-49.

Caston, V. N. D., 1972: Linear sand banks in the southern North Sea. Sediment., 18, 63-78.

Chen, Y. G., and T. K. Liu, 1996: Sea level changes in the last several thousand years, Penghu Islands, Taiwan Strait. Quat. Res., 45, 254-262.

Chuang, W. S., 1985: Dynamics of subtidal flow in the Taiwan Strait. J. Oceanogr. Soc. Japan, 41, 65-72.

Chuang, W. S., 1986: A note on the driving mechanisms of current in the Taiwan Strait. $J$. Oceanogr. Soc. Japan, 42, 65-72.

Dalrymple, R. W., 1984: Morphology and internal structure of sandwaves in the Bay of Fundy. Sediment., 31, 365-382.

Dyer, K. R., and D. A. Huntley, 1999: The origin, classification and modeling of sand banks and ridges. Cont. Shelf Res., 19, 1285-1330.

Fairbanks, R. G., 1989: A 17,000-year glacio-eustatic sea-level record- influence of glacial melting rates on the Younger Dryas event and deep-ocean circulation. Nature, 342, 637-642.

Fan, K. L., 1982 : A study of water masses in Taiwan Strait. Acta Oceanogr. Taiwanica, 13, 140-153.

Houbolt, J. H. C., 1968: Recent sediments in the Southern Bight of the North Sea. Geol. Mijnbouw, 47, 245-273.

Huang, Z. Y., and H. S. Yu, 2003: Morphology and geologic implications of Penghu Channel off southwest Taiwan. Terr. Atmos. Ocean. Sci., 14, 469-485.

Hulscher, S. J. M., H. E. DeSwart, and H. J. DeVriend, 1993: The generation of offshore tidal sand banks and sand waves. Cont. Shelf Res., 13, 1183-1204.

Jan, S., C. S. Chern, J. Wang, and S. Y. Chao, 2004: The anomalous amplication of M2 tide in the Taiwan Strait. Geophy. Res. Lett., 31, L07308.

Jan, S., J. Wang, C. S. Chern, and S. Y. Chao, 2002: Seasonal variation of the circulation in the Taiwan Strait. J. Mar. System, 35, 249-268.

Johnson, H. D., 1978: Shallow siliciclastic seas. In: Reading, H. G. (Ed.), Sedimentary Environments and Facies, Blackwell Scientific Publications, 207-257.

Laban, C., R. T. E. Schuttenhelm, 1981: Some new evidence on the origin of the Zealand ridges. In: Nio, S. D., R. T. E. Schuttenhelm, and T. C. E. van Weering (Eds.), Holocene Marine Sedimentation in the North Sea Basin. Publ. Int. Assoc. Sediment., 5, 239-245.

Lanckneus, J., G. De Moor, and A. Stolk, 1994: Environmental setting, morphology and volumetric evolution of the Middelkerke Bank (southern North Sea). Mar. Geol., 121, 1-21. 
Li, C. Y., and J. C. Chen, 2001: Textural, mineralogical and chemical characteristics of surface marine sediments around Taiwan. Acta Oceanogr. Taiwanica, 39, 67-81.

Liang, W. D., T. Y. Tang, Y. J. Yang, M. T. Ko, and W. S. Chuang, 2003: Upper-ocean currents around Taiwan. Deep Sea Res. II, 50, 1085-1105.

Liu, Z. X., D. X. Xia, S. Berne, K. Y. Wang, T. Marsset, Y. X. Tang, and J. F. Bourrllet, 1998: Tidal deposition systems of continental shelf, with special reference to the eastern Bohai Sea. Mar. Geol., 145, 225-253.

Liu, C. S., S. Y. Liu, S. Lallemand, N. Lundberg, and D. Reed, 1998: Digital elevation model offshore Taiwan and its tectonic implications. Terr. Atmos. Ocean. Sci., 9, 705-738.

Mao, S., and I. H. Hsieh, 1989: Morphology of the Taiwan Strait. In: Nieh, S. P. (Ed.), The Investigation and Study on Petroleum Geology and Geophysics in the Western Taiwan Strait, Ocean Press, Beijing, 22-34. (in Chinese)

McCave, I. N., and D. N. Langhorne, 1982: Sand waves and sediment transport around the end of a tidal sand bank. Sediment., 29, 95-110.

Off, T., 1963: Rhythemic linear sand bodies caused by tidal currents. AAPG Bull., 47, 324341.

Park, S. C., and S. D. Lee, 1994: Depositional patterns of sand ridges in tide-dominated shallow water environments: Yellow Sea coast and South Sea of Korea.Mar. Geol., 120, $89-103$.

Park, S. C., H. S. Han, and D. G. Yoo, 2003: Transgressive sand ridges on the mid-shelf of the southern sea of Korea (Korea Strait): formation and development in high-energy environments. Mar. Geol., 193, 1-18.

Pattiaratchi, C., and M. Collins, 1987: Mechanisms for linear sandbank formation and maintenance in relation to dynamical oceanographic observations. Prog. Oceanogr., 19, 117-176.

Stride, A. H. (Ed.), 1982: Offshore Tidal Sands. Processes and Deposits. Chapman \& Hall, London, $222 \mathrm{pp}$.

Sun, C. S., 1982: The Tertiary basins of offshore Taiwan. Proc. 2nd ASCOPE Conf. Exhibition, Manila, Philippines, 125-135.

Wang, J., and C. S. Chern, 1989: On cold water intrusions in the eastern Taiwan Strait during cold season. Acta Oceanogr. Taiwanica, 22, 43-67.

Wang, J., and C. S. Chern, 1992: On the distribution of bottom cold waters in Taiwan Strait during summer time. La Mer., 30, 213-221.

Wang, Y. H., S. Jan, and D. P. Wang, 2003: Transports and tidal current estimates in the Taiwan Strait from shipboard ADCP observations (1999-2001). Estuarine, Coastal Shelf Sci., 57, 193-199.

Wang, Y. H., L. Y. Chao, K. M. M. Lwiza, and D. P. Wang, 2004: Analysis of flow at the gate of Taiwan Strait. J. Geophys. Res., 109, C02025.

Williams, J. J., N. J. MacDonald, B. A. O'Connor, and S. Pan, 2000: Offshore sand bank dynamics. J. Mar. Sys., 24, 153-173.

Yang, C. S., 1989: Active, moribund and buried tidal sand ridges in the East China Sea and the Southern Yellow Sea. Mar. Geol., 88, 97-116. 
Yu, H. S., 2003: Geological characteristics and distribution of submarine physiographic features in the Taiwan region. Mar. Geores. \& Geotech., 21, 139-153.

Yu, H. S., and Y. W. Chou, 2001: Physiographic and geological characteristics of shelves in north and west of Taiwan. Sci. China, Series D, 44, 696-707.

Yu, H. S., and G. S. Song, 2000: Submarine physiographic features in Taiwan region and their geological significance. J Geol. Soc. China, 43, 267-286. 